\title{
Analysis of the Relationship Between Organizational Entrepreneurship and the Performance of Qom Telecom Center with the Role of Moderating Perceived Environmental Factors
}

\author{
Mohammad Karehvand \\ Department of Management, Naragh Branch, Islamic Azad University, Naragh, Iran
}

\begin{abstract}
Nowadays, environmental circumstances and business rules of organizations are complicate, active and uncertain, so, they cannot assurance their long- term survival through some actions such as, structural changes and methods or relying on creativity of some people in organization. Companies and organizations should prepare conditions to institutionalize entrepreneurial culture in their organization. Corporate entrepreneurship can improve the value of the organization. The entrepreneurial oriented organizations are more responsive for environment and market changes. Opportunity recognition is the base of being successful. The research is applied and in terms of method is descriptive. Data were analyzed, using Linear Regression and Multiple Moderated Regression (MMR) and SPSS software. In this research the effects of organizational entrepreneurship (innovation, proactiveness and risk-taking) on performance of the centers influenced by environmental factors (government's strategies, competitiveness and technology) as moderating variables, were studied. Furthermore, the study presents that there is a significant positive relationship between organizational entrepreneurship and performance. Although the study does not show any significant moderating effect of environmental factors (Government's strategies, competitiveness and technology) on the relationship between organizational entrepreneurship and performance, however, the result of the study manifests direct relationship between environmental factors and performance of such centers.
\end{abstract}

Keywords: entrepreneurship; organizational entrepreneurship; organization performance; risk-taking; innovation; environmental factors

\section{Introduction}

The global economy is creating a fundamental and fundamental change for organizations and industries around the world. These changes require business companies to carefully examine their goal and pay much attention to the selection and pursuit of strategies that will lead to levels of success for many stakeholders. Many established companies have created a foundation for their own operations in response to the rapid and dramatic changes that have taken place in their internal and external environment. Indeed, some of these companies do not resemble their ancestors after years of restructuring, advancement, business, or competition. The new century has witnessed corporate emphasis on innovation, among which entrepreneurship is referred to as the development engine. If development is to use the human and material forces of society for quantitative and qualitative social, cultural and economic changes in order to create a better life (Masterzadeh, 2003), such changes entail economic growth, improving quality of life, optimizing the use of technology and industry, Development of rural areas, training of decent human resources, organizational and administrative reforms, education, etc. Considering the high impact of organizational entrepreneurship on performance, in order to increase and improve the company's performance and to solve the problem of gradual decrease - the years of decline in profitability and other performance criteria of the telecommunication company, the attention of the company's managers to the issue of organizational entrepreneurship in telecommunication centers, taking into account factors An environment that influences them, and promoting entrepreneurship culture within these centers can be promising.

\section{Previous research}


Ghasemiyeh and Abdollahi (2012) in an empirical study titled "Explaining the Effectiveness of Corporate Entrepreneurial Actions on Performance" examined the effect of corporate entrepreneurial behavior on company performance. In this study, five dimensions were considered to examine the variable "corporate entrepreneurial behavior": Innovation, Pioneering and Risk, Reconstruction, and New Business Creation. On the other hand, to examine the performance variable, three dimensions: employee satisfaction, customer satisfaction, employee perception and financial performance were studied. The results of this study indicated that there is a positive and significant relationship between the five dimensions of organizational entrepreneurship (except risk taking) and triple dimensions of company performance (except employee satisfaction). The results of this study also showed that among the dimensions of corporate entrepreneurship, the concept of "creating new business" has the most positive effect on the company's performance.

Mirfakhreddini, Zare Ahmadabadi and Dashtaki (2012) studied the relationship between corporate entrepreneurship and organizational performance in a research entitled "The Study of the Relationship between Corporate Entrepreneurship and Excellence in Organizational Performance in Pishgaman Coir Company of Yazd". The results of this research indicated that corporate entrepreneurship (with dimensions: innovation, self-development, pioneering, risk taking) along with the variables of organizational culture, organizational environment and internal organization components have a direct effect on the performance of the pioneering companies.

Ebrahimpour, Salehi and Khalili (2011) in a study entitled "The Study of the Relationship between Organizational Entrepreneurship and Business Performance of the Company in Tabriz Proshimi" showed that: Among the components of entrepreneurial organization including innovation, pseudo riskiness and invasion competition, with commercial performance, There is a positive and significant relationship.

Atalay, Anafartha and Saravan (2013), in a study entitled "The relationship between innovation and company performance", which took place on 113 Turkish car companies, showed that technological innovations (product innovation and process innovation ) As one of the dimensions of organizational entrepreneurship, has a significant and positive effect on the company's performance.

A study by Mohammad and et al. (2011) on Indonesian companies of moderate size showed that entrepreneurial activity and company performance are positively correlated. This study showed that external factors moderating factors such as government and economy policies modify the relationship between organizational entrepreneurship and firm performance. This research has shown that, among the three dimensions of organizational entrepreneurship (pioneering, innovation, and risk taking), there is a direct relationship with the company's performance. Two other dimensions, innovation and risk taking, contribute to the process of changing company performance and help it.

Akatan and Bolot (2008) in a study entitled "The Effects of Entrepreneurship in Emerging Markets on 312 Active Companies in Turkey," showed that among the dimensions of entrepreneurial organization (in terms of innovation, pioneering, competitive invasion and risk There is a positive and significant relationship with financial performance of the company (market share, return on sales, return rates, profitability), in which the dimension of innovation is most important.3.

\section{Methodology}

\section{3-1-Descriptive statistics}

In this section, the demographic characteristics of the statistical sample are described. The features that are analyzed in this section are: gender, age, level of education and marriage.

- Characteristics of the statistical society of employees by age 
As shown in Table 3.1, 1.2\% of respondents aged 20-30 years, 4.8\% between 30-40 years, 66.6\% between $40-50$ years, and $22.6 \%$ higher than 50 Years old Also, $4.8 \%$ of respondents did not respond to this question. The frequency of respondents' age is presented below.

Table (3-1): Frequency distribution of of respondents' age

\begin{tabular}{|c|c|c|}
\hline Age group & Frequency & Frequency percentage \\
\hline 20 to 30 years & 1 & 1.2 \\
\hline 30 to 40 years & 4 & 4.8 \\
\hline 40 to 50 years & 56 & 66.6 \\
\hline More than 50 years old & 19 & 22.6 \\
\hline Not answered & 4 & 4.8 \\
\hline Total & 84 & 100 \\
\hline
\end{tabular}

- The characteristics of the statistical society of employees

As shown in Table 3-2. 1.2\% of the respondents ranged between 1 and 10 years, $21.4 \%$ between 10 and 20 years, $73.8 \%$ were between 20 and 30 years of age. Also, $3.6 \%$ of respondents did not respond to this question. The frequency of respondent service records is presented below.

Table (3-2): Frequency distribution related to the service life of respondents

\begin{tabular}{|r|l|l|}
\hline Years of service & Frequency & Frequency percentage \\
\hline Between 1 to 10 years & 1 & $1 / 2$ \\
\hline Between 10 and 20 years & 18 & $21 / 4$ \\
\hline Between 20 and 30 years & 62 & $73 / 8$ \\
\hline Not answered & 3 & $3 / 6$ \\
\hline Total & 84 & 100 \\
\hline
\end{tabular}

- Characteristics of the statistical society of employees in terms of education

As shown in Table 3-3, 20.3\% of the respondents had undergraduate degrees, $55.9 \%$ had undergraduate degrees, $19 \%$ had undergraduate and $1.3 \%$ had $\mathrm{PhD}$ degrees. Also, $3.5 \%$ of respondents did not respond to this question. The frequency of respondents' education levels is presented below.

Table (3-3): Frequency distribution of statistical sample members based on work experience

\begin{tabular}{|c|c|c|}
\hline Education & Frequency & Frequency percentage \\
\hline Diploma & 17 & $20 / 3$ \\
\hline Associate Degree & 47 & $55 / 9$ \\
\hline Bachelor & 16 & 19 \\
\hline Masters degree and higher & 1 & $1 / 3$ \\
\hline Not answered & 3 & $3 / 5$ \\
\hline Total & 84 & 100 \\
\hline
\end{tabular}

- The characteristics of the statistical population of the employees according to the history of respondent management

As shown in Table 3-4, 19\% of respondents between 1 to 5 years, 34.5\% between 5 to 10 years, $23.8 \%$ between 10 to 15 years, $5.9 \%$ between $15 \mathrm{Up}$ to 20 years and $7.2 \%$ over 20 years of management experience. Also, 9.6\% of respondents did not respond to this question. The frequency of respondent management history is presented below. 
Table (3-4): Frequency distribution of statistical sample members based on work experience

\begin{tabular}{|c|c|c|}
\hline Experience & Frequency & Frequency percentage \\
\hline Between 1 and 5 years & 16 & 19 \\
\hline Between 5 and 10 years & 29 & $34 / 5$ \\
\hline Between 10 and 15 years & 20 & $23 / 8$ \\
\hline Between 15 and 20 years & 5 & $5 / 9$ \\
\hline More than 20 years old & 6 & $7 / 2$ \\
\hline Not answered & 8 & $9 / 6$ \\
\hline Total & 84 & 100 \\
\hline
\end{tabular}

\section{3-2 Normality of data}

Shapiro-Wilk test was used to test the normal variables, the results of which are presented in the following table. As can be seen, considering the significance level of the test which is above 0.05 , the assumption of the normality of the data is confirmed.

Table (3-5): The results of the test for data normalization based on Shapiro-Wilk test

\begin{tabular}{|c|c|}
\hline Variable Name & Meaningful Level \\
\hline Entrepreneurship Organizational & $0 / 235$ \\
\hline Perceived environment & $0 / 231$ \\
\hline Company performance & $0 / 06$ \\
\hline
\end{tabular}

Also, to test the normality of the variables, a skidding and stretching test can be used, the results of which are presented in Table 3-6 below. As can be seen, considering the fact that the range of slip and stretching numbers is between 1 and 1 , it is confirmed by the assumption of normality of data (Plant, 2009).

Table (3-6): The results of normal data test

\begin{tabular}{|c|c|c|}
\hline Variable Name & Skewness & Kurtosis \\
\hline Entrepreneurship Organizational & $-0 / 204$ & $-0 / 208$ \\
\hline Perceived competition & $-0 / 276$ & $-0 / 891$ \\
\hline Perceived government policies & $-0 / 119$ & $-0 / 524$ \\
\hline Perceived Technology & $-0 / 069$ & $-0 / 541$ \\
\hline Company performance & $-0 / 288$ & $-0 / 063$ \\
\hline
\end{tabular}

\subsection{Inferential statistics}

In this section, we analyze the questionnaires distributed among the statistical sample and analyze the data obtained from them.

\subsubsection{Study of the first hypothesis:}

Organizational Entrepreneurship has a positive and significant effect on the performance of telecoms companies of Qom Telecom.

Table (3-7): Simple linear regression test for the first hypothesis

\begin{tabular}{|l|l|l|l|l|l|}
\hline Model & R & R Square & & & Change Statistics \\
\hline
\end{tabular}




\begin{tabular}{|l|l|l|l|l|l|l|l|l|l|l|}
\hline & & & $\begin{array}{l}\text { Adjusted } \\
\text { Square }\end{array}$ & $\begin{array}{l}\text { Standard } \\
\text { Deviation }\end{array}$ & $\begin{array}{l}\text { R Square } \\
\text { Change }\end{array}$ & $\begin{array}{l}\text { Changes } \\
\text { F }\end{array}$ & df1 & df2 & $\begin{array}{l}\text { Sig. F } \\
\text { Change }\end{array}$ \\
\hline 1 & 0.424 & 0.180 & 0.170 & 0.4891 & 0.180 & 17.984 & 1 & 82 & 0.000 \\
\hline
\end{tabular}

As seen in Table 3-7. The overall model in the relationship between organizational entrepreneurship and company performance is $R^{2}=0.18$ ( $\left.F=17.984, \mathrm{p}>0.50\right)$. Also, the overall model (No. 1) of entrepreneurship is organizational, $18 \%$ of the company's variance in the telecommunications companies of the province Qom explains.

Table (3-8):The value of the coefficients for the first hypothesis

\begin{tabular}{|c|c|c|c|c|c|c|}
\hline \multirow{2}{*}{ Model } & \multicolumn{2}{|c|}{$\begin{array}{c}\text { R Non-standard } \\
\text { Coefficients }\end{array}$} & $\begin{array}{c}\text { Standard } \\
\text { Coefficients }\end{array}$ & Statistics T & $\begin{array}{c}\text { Meaningful } \\
\text { Number }\end{array}$ & Tolerance \\
\cline { 2 - 6 } & B & $\begin{array}{c}\text { Standard } \\
\text { Error }\end{array}$ & Beta coefficient & & \\
\cline { 2 - 5 } Constant & $2 / 219$ & $0 / 329$ & - & $6 / 750$ & $0 / 000$ & \\
\hline $\begin{array}{c}\text { Entrepreneurship } \\
\text { Organizational }\end{array}$ & $0 / 421$ & $0 / 099$ & $0 / 424$ & $4 / 241$ & $0 / 000$ & 1 \\
\hline
\end{tabular}

According to Table 3-8 of the regression model, the first hypothesis of the study is as follows:

$\mathrm{PER}=\mathrm{b} 0+\mathrm{b} 1(\mathrm{ENT})+\dot{\varepsilon}$

$\mathrm{PER}=2.219+0.421(\mathrm{ENT})+\dot{\varepsilon}$

\subsubsection{Study of the second hypothesis:}

The perceived competition modifies the impact of organizational entrepreneurship on the performance of telecom companies in Qom.

Table (3-9): Multiple regression test for the second hypothesis

\begin{tabular}{|c|c|c|c|c|c|c|c|c|c|}
\hline \multirow[b]{2}{*}{ Model } & \multirow[b]{2}{*}{$\mathbf{R}$} & \multirow[b]{2}{*}{ R Square } & \multirow{2}{*}{$\begin{array}{l}\text { Adjusted R } \\
\text { Square }\end{array}$} & \multirow{2}{*}{$\begin{array}{l}\text { Standard } \\
\text { Deviation }\end{array}$} & \multicolumn{5}{|c|}{ Change Statistics } \\
\hline & & & & & $\begin{array}{l}\text { R Square } \\
\text { Change }\end{array}$ & $\begin{array}{l}\text { Changes } \\
\text { F }\end{array}$ & df1 & df2 & $\begin{array}{l}\text { Sig. F } \\
\text { Change }\end{array}$ \\
\hline 1 & (a) $0 / 424$ & $0 / 180$ & $0 / 160$ & $0 / 4921$ & $0 / 180$ & $8 / 882$ & 2 & 81 & $0 / 000$ \\
\hline 2 & (b) $0 / 454$ & $0 / 206$ & $0 / 176$ & $0 / 4872$ & $0 / 026$ & $2 / 624$ & 1 & 80 & $0 / 109$ \\
\hline
\end{tabular}

a Predictors: (Constant), CO Perceived competition, ENT Entrepreneurship Organizational

b Predictors: (Constant), CO Perceived competition, ENT Entrepreneurship Organizational, ENT.CO

c Dependent Variable: PER, Company performance

As seen in Table 3-9. The overall model in the relationship between organizational entrepreneurship and firm performance is significant $\mathrm{R} 2=0.18(\mathrm{~F}=8.882, \mathrm{p}<0.05)$. In the general model (No. 1), entrepreneurial organization with perceived competition, $18 \%$ of the company's variance in The telecommunication centers of Qom province province telecomunication are explained in Model No. 2 in the table above shows the relationships between variables after entering the perceived competitiveness variable. As seen, there is no significant change in the $2 \mathrm{R}$ and is about Also, the significance level is more than $0 / 05$. Therefore, the role of perceived competition moderation in the 
relationship between organizational entrepreneurship and firm performance is not confirmed. In connection with the second hypothesis is presented in Figure 3-1.
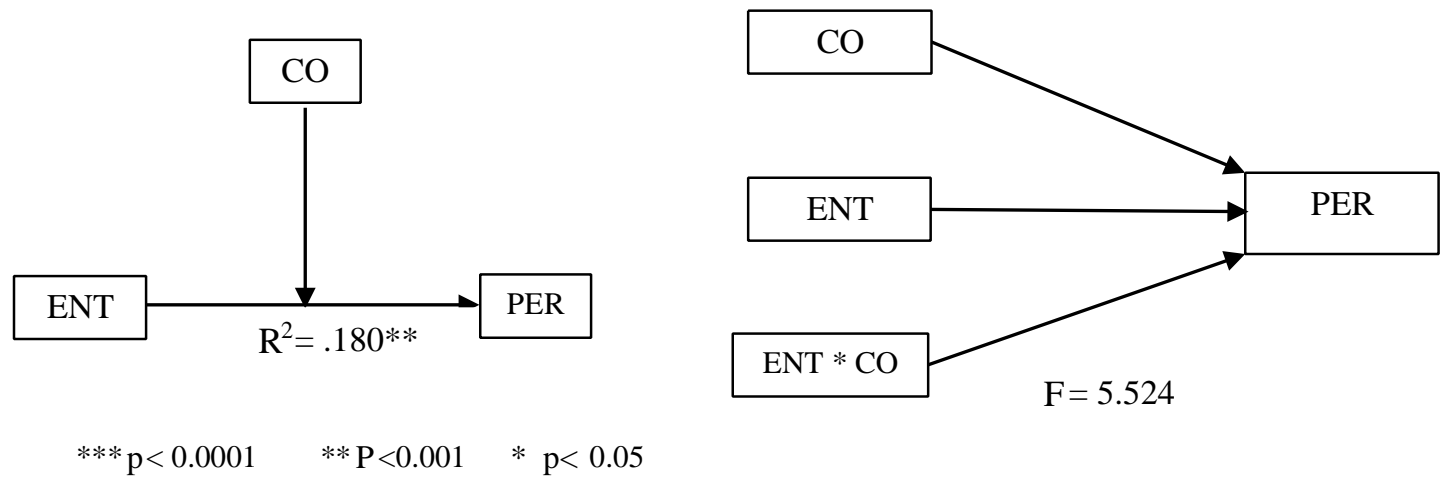

Figure 3-1: The research model for examining the second hypothesis

In Table 3-10, the value of the coefficients for the hypothesis of the second hypothesis is presented:

Table (3-10): The value of the coefficients for the second hypothesis

\begin{tabular}{|c|c|c|c|c|c|c|c|}
\hline \multirow{3}{*}{ Model } & \multirow{2}{*}{\multicolumn{2}{|c|}{$\begin{array}{l}\text { R Non-standard } \\
\text { Coefficients }\end{array}$}} & \multirow{3}{*}{$\begin{array}{c}\begin{array}{c}\text { Standard } \\
\text { Coefficients }\end{array} \\
\text { Beta } \\
\text { coefficient }\end{array}$} & \multirow{3}{*}{$\begin{array}{c}\text { Statistics } \\
\mathbf{T}\end{array}$} & \multirow{3}{*}{$\begin{array}{c}\text { Meaningful } \\
\text { Number }\end{array}$} & \multicolumn{2}{|c|}{ Collinearity Statistics } \\
\hline & & & & & & \multirow{2}{*}{ Tolerance } & \multirow{2}{*}{ VIF } \\
\hline & B & $\begin{array}{c}\text { Standard } \\
\text { Error } \\
\end{array}$ & & & & & \\
\hline Constant & $2 / 226$ & $0 / 644$ & - & $3 / 458$ & $0 / 001$ & - & - \\
\hline $\begin{array}{c}\text { Entrepreneurship } \\
\text { Organizational }\end{array}$ & $0 / 421$ & $0 / 1$ & $0 / 424$ & $4 / 213$ & $0 / 000$ & 0/999 & $1 / 001$ \\
\hline Perceived competition & $-0 / 001$ & $0 / 121$ & $-0 / 001$ & $-0 / 012$ & $0 / 990$ & $0 / 999$ & $1 / 001$ \\
\hline Constant & $-3 / 691$ & $3 / 708$ & - & $-0 / 995$ & $0 / 323$ & - & - \\
\hline $\begin{array}{c}\text { Entrepreneurship } \\
\text { Organizational }\end{array}$ & $2 / 199$ & $1 / 102$ & $2 / 217$ & $1 / 995$ & $0 / 049$ & $0 / 008$ & $124 / 397$ \\
\hline Perceived competition & $1 / 133$ & $0 / 832$ & $1 / 107$ & $1 / 601$ & $0 / 113$ & $0 / 021$ & $48 / 190$ \\
\hline $\begin{array}{c}\text { Organizational } \\
\text { Entrepreneurship } \\
\text { *Perceived } \\
\text { Competition }\end{array}$ & $-0 / 401$ & $0 / 248$ & $-2 / 086$ & $-1 / 620$ & 0/109 & $0 / 006$ & $167 / 019$ \\
\hline
\end{tabular}

According to Table 3-10 of the regression model, the second hypothesis of the research is as follows:

$\mathrm{PER}=\mathrm{b} 0+\mathrm{b} 1(\mathrm{ENT})+\mathrm{b} 2(\mathrm{CO})+\mathrm{b} 3(\mathrm{ENT} . \mathrm{CO})+\dot{\varepsilon}$

$\mathrm{PER}=-3.691+2.199(\mathrm{ENT})+1.133(\mathrm{CO})-.401(\mathrm{ENT} . \mathrm{CO})+\dot{\varepsilon}$ 


\subsubsection{Study of the third hypothesis:}

Perceived government policies modify the effect of organizational entrepreneurship on the

Table (3-11): Multiple regression analysis for the third hypothesis

\begin{tabular}{|c|c|c|c|c|c|c|c|c|c|}
\hline \multirow{2}{*}{ Model } & \multirow{2}{*}{$\mathbf{R}$} & \multirow{2}{*}{$\begin{array}{l}\text { R } \\
\text { Square }\end{array}$} & \multirow{2}{*}{$\begin{array}{l}\text { Adjusted R } \\
\text { Square }\end{array}$} & \multirow{2}{*}{$\begin{array}{l}\text { Standard } \\
\text { Deviation }\end{array}$} & \multicolumn{5}{|c|}{ Change Statistics } \\
\hline & & & & & $\begin{array}{l}\text { R Square } \\
\text { Change }\end{array}$ & Changes F & df1 & df2 & $\begin{array}{l}\text { Sig. F } \\
\text { Change }\end{array}$ \\
\hline 1 & $0 / 424(a)$ & $0 / 180$ & $0 / 160$ & $0 / 4920$ & $0 / 180$ & $8 / 891$ & 2 & 81 & $0 / 000$ \\
\hline 2 & $0 / 427(b)$ & $0 / 182$ & $0 / 152$ & $0 / 4944$ & $0 / 002$ & $0 / 225$ & 1 & 80 & $0 / 636$ \\
\hline
\end{tabular}

a Predictors: (Constant), GP Perceived competition, ENT Entrepreneurship Organizational

b Predictors: (Constant), GP Perceived competition, ENT Entrepreneurship Organizational, ENT. GP

c Dependent Variable: PER, Company performance

As seen in Table 3-11. The overall model in the relationship between organizational entrepreneurship and firm performance is significant $(\mathrm{R} 2=0.18(\mathrm{~F}=8.891, \mathrm{p}<0.05)$. In general model (No.1), entrepreneurship with perceived government policies, $18 \%$ of variance of performance Participating in the telecommunication centers of the telecom company of the province of Qom province, model No. 2 in the table above shows the relationship between variables after entering the variable of perceived government policies. As seen in $2 \mathrm{R}$, no significant change has been made. And is about 0.002. Also, the meaningful number is more than 0.05 . Therefore, the role of moderating perceived government policies in the relationship between organizational entrepreneurship and performance The research model is presented in conjunction with the third hypothesis in Figure 3-2.
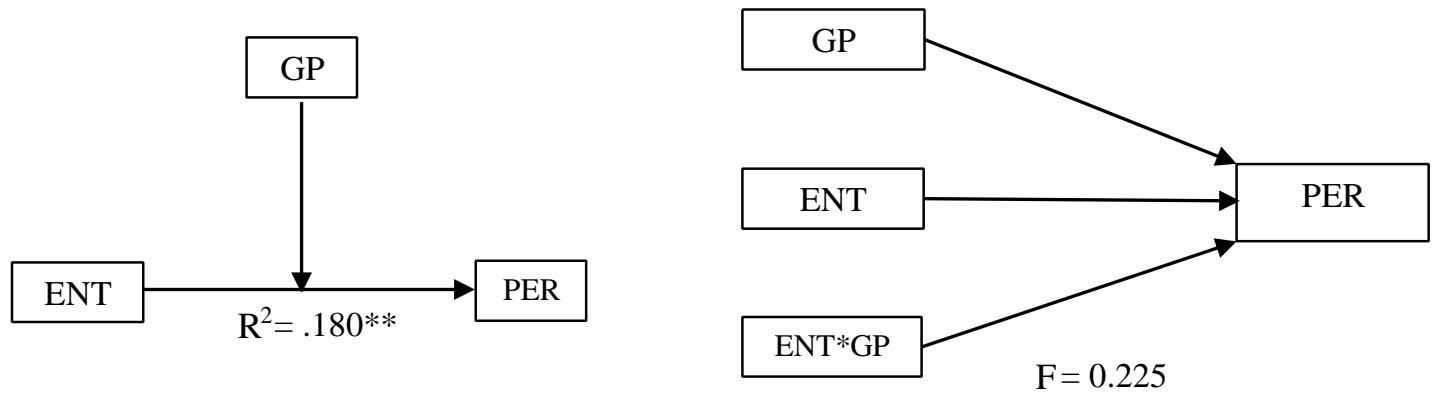

$* * * \mathrm{p}<0.0001 \quad * * \mathrm{P}<0.001 \quad * \mathrm{p}<0.05$

Figure 3-2: The research model for examining the third hypothesis

In Table 3-12, the value of the coefficients for the hypothesis of the third hypothesis is presented:

Table (3-12): The value of the coefficients for the third hypothesis

\begin{tabular}{|c|c|c|c|c|c|c|c|}
\hline \multirow{2}{*}{ Model } & \multicolumn{2}{|c|}{$\begin{array}{c}\text { R Non-standard } \\
\text { coefficients }\end{array}$} & $\begin{array}{c}\text { Standard } \\
\text { Coefficients }\end{array}$ & \multirow{2}{*}{$\begin{array}{c}\text { Statistics } \\
\text { T }\end{array}$} & $\begin{array}{c}\text { Meaningful } \\
\text { Number }\end{array}$ & Tolerance & \multicolumn{2}{|c|}{ VIF } \\
\cline { 2 - 3 } & B & $\begin{array}{c}\text { Standard } \\
\text { Error }\end{array}$ & $\begin{array}{c}\text { Beta } \\
\text { Coefficient }\end{array}$ & & & & \\
\hline Constant & $2 / 264$ & $0 / 5$ & - & $4 / 527$ & $0 / 000$ & - & - \\
\hline $\begin{array}{c}\text { Entrepreneurship } \\
\text { Organizational }\end{array}$ & $0 / 424$ & $0 / 103$ & $0 / 427$ & $4 / 103$ & $0 / 000$ & $0 / 933$ & $1 / 071$ \\
\hline
\end{tabular}




\begin{tabular}{|c|c|c|c|c|c|c|c|}
\hline $\begin{array}{c}\text { Perceived } \\
\text { government policies }\end{array}$ & $-0 / 013$ & $0 / 110$ & $-0 / 013$ & $-0 / 120$ & $0 / 905$ & $0 / 933$ & $1 / 071$ \\
\hline Constant & $3 / 453$ & $2 / 552$ & - & $1 / 353$ & $0 / 180$ & - \\
\hline $\begin{array}{c}\text { Entrepreneurship } \\
\text { Organizational }\end{array}$ & $0 / 053$ & $0 / 788$ & $0 / 053$ & $0 / 067$ & $0 / 946$ & $0 / 016$ & $61 / 713$ \\
\hline $\begin{array}{c}\text { Perceived } \\
\text { government policies } \\
\begin{array}{c}\text { Organizational } \\
\text { Entrepreneurship* } \\
\text { Perceived } \\
\text { Government } \\
\text { Policies }\end{array}\end{array}$ & $-0 / 299$ & $0 / 612$ & $-0 / 283$ & $-0 / 489$ & $0 / 626$ & $0 / 03$ & $32 / 904$ \\
\hline
\end{tabular}

According to Table 3-12, the regression model of the third hypothesis of the research is as follows:

$\mathrm{PER}=\mathrm{b}_{0}+\mathrm{b}_{1}(\mathrm{ENT})+\mathrm{b}_{2}(\mathrm{GP})+\mathrm{b}_{3}(\mathrm{ENT} . \mathrm{GP})+\dot{\varepsilon}$

$\mathrm{PER}=3.453+0.53(\mathrm{ENT})-0.299(\mathrm{GP})+0.089(\mathrm{ENT} . \mathrm{GP})+\dot{\varepsilon}$

\subsubsection{Study of the Fourth hypothesis:}

The perceived technology modifies the effect of organizational entrepreneurship on the performance of telecom centers of Qom Telecom.

Table (3-13): Multiple regression analysis for the fourth hypothesis

\begin{tabular}{|c|c|c|c|c|c|c|c|c|c|}
\hline \multirow{2}{*}{ Model } & \multirow{2}{*}{$\mathbf{R}$} & \multirow{2}{*}{$\begin{array}{l}\text { R } \\
\text { Square }\end{array}$} & \multirow{2}{*}{$\begin{array}{l}\text { Adjusted R } \\
\text { Square }\end{array}$} & \multirow{2}{*}{$\begin{array}{l}\text { Standard } \\
\text { Deviation }\end{array}$} & \multicolumn{5}{|c|}{ Change Statistics } \\
\hline & & & & & $\begin{array}{l}\text { R Square } \\
\text { Change }\end{array}$ & $\begin{array}{l}\text { Changes } \\
\text { F }\end{array}$ & df1 & df 2 & $\begin{array}{l}\text { Sig. F } \\
\text { Change }\end{array}$ \\
\hline 1 & $0 / 437$ (a) & $0 / 191$ & $0 / 171$ & $0 / 4887$ & $0 / 191$ & $9 / 572$ & 2 & 81 & $0 / 000$ \\
\hline 2 & $0 / 440(b)$ & $0 / 194$ & $0 / 164$ & $0 / 4909$ & $0 / 003$ & $0 / 280$ & 1 & 80 & $0 / 598$ \\
\hline
\end{tabular}

a Predictors: (Constant), TE Perceived competition, ENT Entrepreneurship Organizational

b Predictors: (Constant), TE Perceived competition, ENT Entrepreneurship Organizational, , ENT.CO c

c Dependent Variable: PER, Company performance

As seen in Table 3-13. The overall model in the relationship between organizational entrepreneurship and firm performance is significant $\mathrm{R} 2=0.19(\mathrm{~F}=9.572, \mathrm{p}<0.05)$. In the general model (No.1), entrepreneurship with perceived technology is $19 \%$ of the company's variance in centers The telecommunications company of the telecom company explains the province of Qom. Model No. 2 in the table above shows the relationships between variables after entering the perceived technology variable. As can be seen, in $2 \mathrm{R}$, no significant change has been made and is about 003 / 0 . Also, the meaningful number is greater than 0.05 . Therefore, the role of perceived technology modulation in the relationship between organizational entrepreneurship and firm performance is not confirmed.

The research model in relation to the fourth hypothesis is presented in Figure 3-3. 

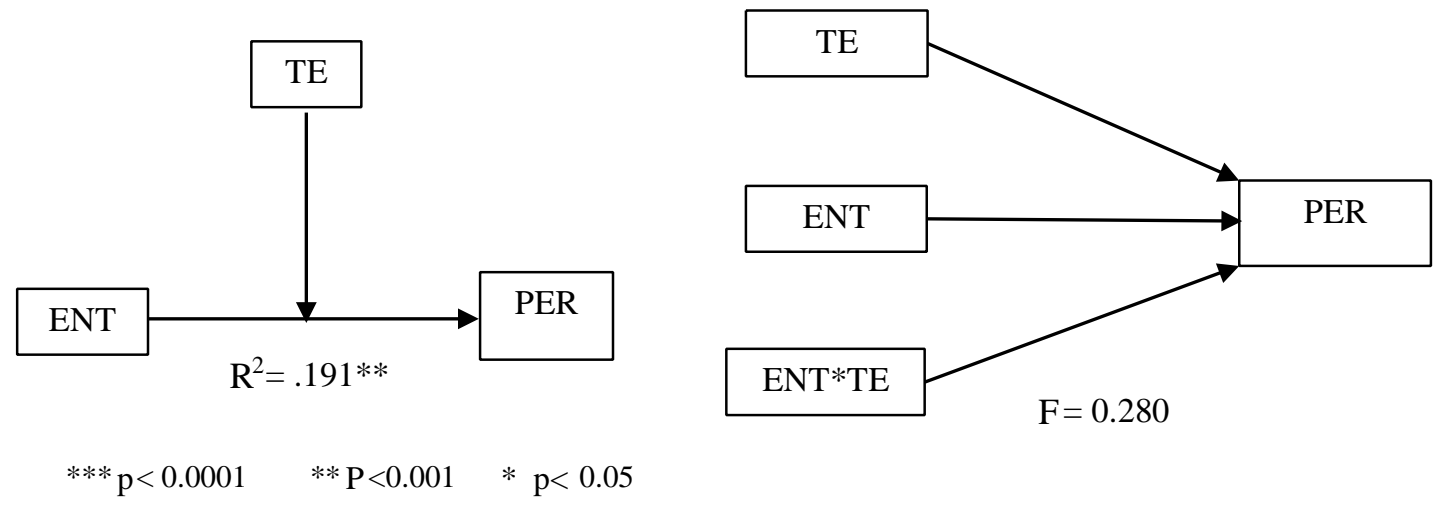

Figure 3-3 The research model for examining the fourth hypothesis

In Table 3-14, the value of the coefficients for the hypothesis of the fourth hypothesis is presented:

Table (3-14): Value of coefficients for the fourth hypothesis

\begin{tabular}{|c|c|c|c|c|c|c|c|}
\hline \multirow{3}{*}{ Model } & \multirow{2}{*}{\multicolumn{2}{|c|}{$\begin{array}{l}\text { R Non-standard } \\
\text { Coefficients }\end{array}$}} & \multirow{3}{*}{$\begin{array}{c}\begin{array}{c}\text { Standard } \\
\text { Coefficients }\end{array} \\
\text { Beta } \\
\text { Coefficient }\end{array}$} & \multirow{3}{*}{$\begin{array}{c}\text { Statistics } \\
\mathbf{T}\end{array}$} & \multirow{3}{*}{$\begin{array}{l}\text { Meaningful } \\
\text { Number }\end{array}$} & \multicolumn{2}{|c|}{ Collinearity Statistics } \\
\hline & & & & & & \multirow{2}{*}{ Tolerance } & \multirow{2}{*}{ VIF } \\
\hline & B & $\begin{array}{c}\text { Standard } \\
\text { Error }\end{array}$ & & & & & \\
\hline Constant & $2 / 264$ & $0 / 5$ & - & $4 / 527$ & $0 / 000$ & - & - \\
\hline $\begin{array}{c}\text { Entrepreneurship } \\
\text { Organizational }\end{array}$ & $0 / 424$ & $0 / 103$ & $0 / 427$ & $4 / 103$ & $0 / 000$ & $0 / 933$ & $1 / 071$ \\
\hline $\begin{array}{c}\text { Perceived } \\
\text { Technology }\end{array}$ & $-0 / 013$ & $0 / 110$ & $-0 / 013$ & $-0 / 120$ & $0 / 905$ & $0 / 933$ & $1 / 071$ \\
\hline Constant & $3 / 453$ & $2 / 552$ & - & $1 / 353$ & $0 / 180$ & - & - \\
\hline $\begin{array}{c}\text { Entrepreneurship } \\
\text { Organizational }\end{array}$ & $0 / 053$ & $0 / 788$ & $0 / 053$ & $0 / 067$ & $0 / 946$ & $0 / 016$ & $61 / 713$ \\
\hline $\begin{array}{c}\text { Perceived } \\
\text { Technology }\end{array}$ & $-0 / 299$ & $0 / 612$ & $-0 / 283$ & $-0 / 489$ & $0 / 626$ & $0 / 03$ & $32 / 904$ \\
\hline $\begin{array}{c}\text { Organizational } \\
\text { Entrepreneurship*P } \\
\text { erceived } \\
\text { Technology }\end{array}$ & $0 / 089$ & $0 / 187$ & $0 / 517$ & $0 / 475$ & $0 / 636$ & $0 / 009$ & $116 / 151$ \\
\hline
\end{tabular}

Also, the regression model of the fourth hypothesis of the research according to Table 3-14 is as follows:

$$
\begin{aligned}
& \mathrm{PER}=\mathrm{b} 0+\mathrm{b} 1(\mathrm{ENT})+\mathrm{b} 2(\mathrm{TE})+\mathrm{b} 3(\mathrm{ENT} . \mathrm{TE})+\dot{\varepsilon} \\
& \mathrm{PER}=1.071+0.919(\mathrm{ENT})+0.263(\mathrm{TE})-0.114(\mathrm{ENT} . \mathrm{TE})+\dot{\varepsilon}
\end{aligned}
$$




\section{Conclusion}

After processing the data by statistical tools and software, the following results were obtained that could confirm or reject the hypotheses proposed in the research. The results are as follows.

\section{Hypothesis 1: Organizational Entrepreneurship has a positive and significant effect on the performance of telecoms company of Qom Telecom.}

In the previous chapter, it was found that organizational entrepreneurship has a positive and meaningful effect on the performance of the urban communication centers of Qom province and, as a result, the first hypothesis is confirmed. The results of this hypothesis are consistent with the results of the researches of Wikilton and Schiff (2005), Akatan and Bulut (2008), Mohammad et al. (2011) and Qhasemieh and Abdollahi (2012).

One of the issues faced by entrepreneurial companies is the dynamic and environmentally-friendly . In dynamic environments, it is obvious that it is impossible to predict customer demands and competitors' capacities, as well as high rates of change in market trends and industry innovation. In such a situation, gaining profit from current operations will be unreliable, and companies will have to search for new opportunities. In this situation, the entrepreneurial thinking of company managers, with features such as the ability to predict changes and clusters to create new processes and provide innovative services before competitors. Gaining competitive advantage and thus improving the performance of organizations (Croves, Michel, Christine, and Jains, 2005). In entrepreneurship, managers are the core of all company activities and play a key and key role in promoting and improving the company's performance. In this way, their entrepreneurial thinking, with characteristics such as innovation, risk taking and pioneering, will be the cornerstone of the company's better performance. These features make managers able to create the necessary organizational chaos in the company and prepare the organization to predict changes in the environment and the market and respond quickly to their needs, thus making it competitive for the company. Features such as innovation and advancement are important factors in maintaining competitive advantage and improving financial achievements.

\section{Second hypothesis: Perceived competition modifies the effect of organizational entrepreneurship on the performance of telecom companies in Qom.}

It was expected that perceived competition would modify the relationship between organizational entrepreneurship and performance, in other words, either exacerbate or weaken the linkage. But this hypothesis was rejected as seen in the second hypothesis in Chapter 4. The results of previous research (Zahra, 1993; A; Lumpkin, 2001; Mohammad et al. 2011) confirmed the moderating effect of environmental factors, including competition, in this regard. However, in explaining why the hypothesis was rejected in the context of this research and its statistical society, it may be said that previous studies have been carried out on developed countries; in these countries, the competitive environment for the operation of successful and well-trained entrepreneurs and highly environmental conflicts, And competition in these countries is also a factor in exacerbating the effect of organizational entrepreneurship on firms' performance. As discussed in the literature, Miller and Friesen (1983) found that changing organizational entrepreneurship among successful firms in Compared to unsuccessful companies, there was a significant and positive correlation with changes in the hostile environment.

In other words, hostility and intense environmental competition reinforce and promote innovation and pioneering (two dimensions of organizational entrepreneurship dimension), and with regard to the subject literature and the positive relationship between organizational entrepreneurship and company performance, the company's performance improves. Given the fact that competition can be viewed from a market or industrial perspective (Kafashpour, 2009), 
from the industrial point of view (and not from the market perspective: because of the market perspective, mobile operators, PAPs and Internet service providers, And ... rival of telecommunication companies), there is no rival for telecommunication companies in the area of establishing and selling fixed telephone services in the country, so there is little controversy for this company, and as the results of this research show Competition can not play a role in modifying the relationship between organizational entrepreneurship and performance. Considering the results of this study, it should be noted here that the direct relationship between competition and organizational entrepreneurship is significant, that is, in this research, competition was one of the variables that had a significant relationship with the performance of telecommunication centers, Which should be considered in future research. However, in this section, it is necessary to point out that limitations, mistakes, subjectivities and ... unintended and unintentional by respondents and researcher may have contributed to the rejection of this hypothesis.

Hypothesis 3: Perceived government policies modify the effect of organizational entrepreneurship on the performance of telecom companies in Qom.

According to the third hypothesis, we expected the moderating role of government policies to be positively correlated with organizational entrepreneurship, in other words, government policies would either exacerbate or weaken this relationship, as the results of previous investigations (Zahra, 1993; A; Lumpkin, 2001; Mohammad et al. 2011) has been evidence of this claim.

In justifying and explaining the rejection of this hypothesis, it can be said that in developed countries, governments do not directly play a role in the economy, but with macroeconomic planning and investment to create infrastructure for development, to create the appropriate legal framework, to create economic and political stability Developing appropriate macroeconomic policies, appropriate relationships and partnerships with foreign countries, attracting investment and participation of companies and foreign institutions, etc., provide a platform for the activity and competition of firms and private sector companies.

In developing countries, including our country, governments have no role in the economy in the economy, but they are directly involved in the economy. In the telecommunication sector of the country, telecommunications has been left to the private sector for only three years (since 2010). This transfer is not complete, but only $50 \%$ of the total share of the shares assigned to the private sector, and 5\% of the employees' contributions (in accordance with the State Service Management Act), the remaining shares owned by the government or under the administration of the government, and this It means monopoly and lack of competitive environment for companies and the private sector.

Moreover, the policies and laws introduced by the government in areas such as pricing (controlling and fixing the price of telecommunications services by the regulatory agency and radiocommunication, or preventing the implementation of an innovative and attractive co-design, only on the pretext of rising prices ), Upgrading and equipping telecommunications systems to new generations of telecom companies. So, as the findings of this research showed, despite the rejection of the hypothesis of the moderating role of government policies in relation to organizational entrepreneurship and firm performance, direct relation between government policies and telecommunications service performance has been confirmed. This shows that government policies directly affect the performance of these centers, and this is the direct involvement of the government, which will be further explored in future studies. It should be noted that the reason for the rejection of this hypothesis may be from respondents and researcher due to limitations, errors, interference of minds and ... uninitial.

\section{Fourth hypothesis: Perceived technology modifies the effect of organizational entrepreneurship on the performance of telecom companies in Qom.}

Based on the literature and previous studies (Mohamed \& Co, 2011), it was expected that the technology, or the technical knowledge used in telecommunication equipment and hardware, would play a moderating role in the relationship between organizational entrepreneurship and the operation of telecommunications centers. In other words, 
the availability of technology and the high technical knowledge used in telecommunication equipment and hardware can enhance and improve the company's performance by enhancing the two dimensions of entrepreneurship (innovation and pioneering) (quality services for the customer, strengthening the company's overall performance from Increasing the speed and quality of data transfer in telecommunication services. However, the moderating effect of this variable on the relationship between organizational entrepreneurship and firm performance was not confirmed. However, the direct effect of technology on performance has been confirmed.

In recent years, with the unprecedented increase in all-embracing US and European sanctions against the country, we have faced difficulties in supplying high-tech equipment in some industrial and service sectors.

The country's contacts have been struggling with this problem. However, in the recent years, there are many problems in telecommunication processing in the field of supply of high-tech components and equipment that is essential for the maintenance and development of telecommunication systems. In some cases, the low quality and technology used in the equipment results in low quality services and, consequently, dissatisfaction with the consultants. However, in this study, the direct effect of technology on the performance of the telecommunications company was not rejected.

\section{References}

Atalay, M., Anafarta, N., \& Sarvan, F. (2013). The Relationship between Innovation and Firm Performance: An Empirical Evidence from Turkish Automotive Supplier Industry. Procedia - Social and Behavioral Sciences, 75(0), 226-235.

Akatan, B., \& Bulut, C. (2008). Financial Performance Impacts of Corporate Entrepreneurship in Emerging Markets: A Case of Turkey. European Journal of Economics, Finance and Administrative Sciences 12, 69-79.

Audit Organization (2012). Report of Independent Auditor and Legal Inspector of Qom Telecommunication Company for Financial Year Ended March 29, 2011.

Audit Organization (2013). Report of Independent Auditor and Legal Inspector of Qom Telecommunication Company for Financial Year Ended March 29, 2012.

Audit Organization (2011). Report of Independent Auditor and Legal Inspector of Qom Telecommunication Company for Financial Year Ended March 29, 2010.

Hajatmand ghale rood khani, h. (2009). Comparative Study of Entrepreneurship Status of Physical Education Students of Public and Non-Governmental Universities. Master's thesis for Physical Education and Sports, Mashhad: Ferdowsi University.

Jebel Ameli, S., Golestan Hashemi, M., Abrahimzadeh, R. (2009). Investigating the Organizational Impact on Creativity and Innovation in the Organization. Presented at the National Conference on Creativity and Engineering, Management and Innovation of Iran. Tehran.

Jimenez, J. D., \& Sanz-Valle, R. (2011). Innovation, organizational learning and performance. Journal of Business Research, 64(4), 408-417.

Jaskyte, K. (2011). Predictors of administrative and technological innovations in nonprofit organizations. Public Administration Review, 71(1), 77-86.

Lumpkin, G. T, \& Dess, G. G. (2001). Linking Two Dimensions of Entrepreneurial Orientation to Firm Performance: The Moderating Role of Environment and Industry Life Cycle. Journal of Business Venturing, 16, 429-451.

Mirfakhreddini, h. Zare Ahmadabadi, H., Dashtiki, AS. (2012). Investigating the Relationship between Corporate Entrepreneurship and Excellence in Organizational Performance in Pishgaman Coir Company of Yazd. Journal of Research in Business Management. Fourth Year, (8), 46-74.

Morgan, N. A. (2012). Marketing and business performance. Journal of the Academy of Marketing Science. 40,102119.

Miller, D., \& Friesen, P. H. (1983). Successful and Unsuccessful Phases of the Corporate Life Cycle. Organization Studies, 4, 339-56. 
Mohammad, O., Ramayah, T., Puspowarsito, H., Natalisa, D., \& Saerang, D. P. E. (2011). Corporate Entrepreneurship and Firm Performance: The Role of Business Environment as a Moderator. [Article]. IUP Journal of Management Research, 10(3), 7-27.

Najafi Siahrodi, M. (2008). Investigating the Effect of Marketing Research on Performance through Marketing Culture in Mashhad Travel Agencies. Master thesis, Ferdowsi University, Mashhad.

Pallant, j. (2009). Spss survival manual, a step by step guide to data analysis using spss for windows (version15). Aleen xuniwn, third edition.

Qhasemieh, R., Abdollahi, H. (2012). Explaining the Relationship between Corporate Entrepreneurial Actions and Company Performance. Development of Entrepreneurship, 46-27, (3) 5.

Rubera, G., \& Kirca, A. (2012). Firm innovativeness and its performance outcomes: A meta-analytic review and theoretical integration. Journal of Marketing, 76(3), 130-147.

Richard, P. J., Devinney, T. M., Yip G. S., \& Johnson, G. (2009). Measuring Organizational Performance: Towards Methodological Best Practice. Journal of Management (June 2009), 35(3), 718-804.

Sekaran, U., \& Bougie, R. (2010). Research Metthod for Business, (5th) edition. USA: john wiley \& sons, INC.

Zahra, S. A. (1993b). A Conceptual Model of Entrepreneurship as Firm Behavior: A Critique and Extension. Entrepreneurship Theory and Practice, 16(4). 